\title{
Free Trade: Why Are Economists and Noneconomists So Far Apart?
}

\author{
William Poole
}

F ree trade-are you fer it or agin it? Why? I'm sure that this audience knows that most economists support free trade policies; however, public support for these policies can be characterized as lukewarm at best and certain groups are adamantly opposed. It is not unusual to hear the following reservations expressed about trade: "Trade harms large segments of U.S. workers." "Trade degrades the environment." "Trade exploits poor countries." We have all heard these criticisms and lots of others.

Many economists, including me, try to change public attitudes by explaining the advantages of free trade in speeches and articles intended to reach a wide range of audiences. But, let's face it: We are not very successful in changing public attitudes. Why, and how can we become more persuasive? What I will explore today is the gap that separates economists from the general public. ${ }^{1}$

I'll first present some evidence on the gap between economists and the general public on attitudes toward trade. I'll then outline two principles that help to understand this gap and that help to frame revealing questions when studying particular disputes. Finally, I'll offer a few suggestions on closing the gap.

Before proceeding, I want to emphasize that the views I express are mine and do not necessarily reflect official positions of the Federal Reserve System. I thank my colleagues at the Federal Reserve Bank of St. Louis for their comments; Cletus Coughlin, vice president in the Research Division, was especially helpful. However, I retain full responsibility for errors.

\footnotetext{
1 See Coughlin (2002) for additional discussion of this gap.
}

\section{THE GAP}

A 1990 survey of economists employed in the United States found that more than 90 percent generally agreed with the proposition that the use of tariffs and import quotas reduced the average standard of living. ${ }^{2}$ These results are somewhat dated; however, most observers agree that " $[t]$ he consensus among mainstream economists on the desirability of free trade remains almost universal." 3 I don't have any data to report economists' views on particular trade disputes, but am willing to offer the following assertion: In most specific cases, disinterested economists do not defend trade restriction. By "disinterested economists" I mean economists not hired by firms engaged in the particular disputes and not employed by government agencies involved in the disputes.

If fact, I suspect that disinterested economists' attitudes about specific disputes are even more lopsided in favor of free trade than the 90 percent who generally favor free trade policies. The reason is that specific disputes almost always involve in a pretty obvious way special favors to particular industries. In contrast, economists' attitudes in general are influenced by theoretical cases in which protection may make some sense. I do not want to try to explain these theoretical cases here, but do want to note that actual trade disputes rarely fit such cases.

Let's now consider attitudes held by the general public. Public opinion polls reveal that the attitude of the general public toward free trade is not simply one of either being for free trade or for protection-

\footnotetext{
2 See Alston, Kearl, and Vaughan (1992).

3 See Mayda and Rodrik (2001, p. 1).
}

William Poole is the president of the Federal Reserve Bank of St. Louis. This article was adapted from a speech of the same title presented at the Trade, Globalization and Outsourcing Conference, Reuters America Inc., New York, New York, June 15, 2004. The author thanks colleagues at the Federal Reserve Bank of St. Louis for comments; Cletus Coughlin, vice president in the Research Division, was especially helpful. The views expressed are the author's and do not necessarily reflect official positions of the Federal Reserve System.

Federal Reserve Bank of St. Louis Review, September/October 2004, 86(5), pp. 1-6.

(0) 2004, The Federal Reserve Bank of St. Louis. 
ism. ${ }^{4}$ Questions asking about free trade in principle reveal support for free trade, albeit not as strong as economists'. However, questions asking about free trade in practice reveal strong reservations. That is, when we get to specific trade disputes, public support for free trade tends to crumble, whereas economists rarely support trade restriction in specific disputes.

A majority of Americans do support free trade in principle. A February 2000 survey by the Pew Research Center asked the following question: "In general, do you think that free trade with other countries is good or bad for the United States?" "Good" was the response of 64 percent of the respondents, while "bad" was the response of 27 percent of the respondents. The remaining 9 percent "did not know." The general public's support for free trade is, therefore, a good bit lower than economists' support.

Much evidence exists suggesting that the general public understands the benefits from free trade in terms of increased product selection, higher quality, and lower prices. The Pew Research Center found that 81 percent of the respondents said that it was either "very good" or "somewhat good" that trade makes available different products from different parts of the world. ${ }^{5}$

Despite an intuitive understanding of many of the benefits of free trade, the general public has strong reservations about embracing such a policy. One set of reservations concerns distributional effects of trade. Workers are not seen as benefiting from trade. Strong evidence exists indicating a perception that the benefits of trade flow to businesses and the wealthy, rather than to workers, and to those abroad rather than to those in the United States. A poll taken by the Gallup Organization in November 1999 found that 56 percent believed that increased trade helped American companies, but that only

\footnotetext{
4 A wealth of information on trade opinions can be found at the following website maintained by the Program on International Policy Attitudes: www.americans-world.org/digest/global_issues/intertrade/ trade-general.cfm

5 Other polls find similar results. EPIC-MRA - a polling firm conducting educational, political, industrial, and consumer market research analysis - found large majorities agreeing that trade allows American consumers to have a larger selection of goods to choose from (87 percent), improves the quality of American goods ( 80 percent), and allows low-income families to buy many products that they might not otherwise afford (74 percent). Polling by EPIC-MRA also found that Americans expected that they would either be paying much more ( 24 percent) or somewhat more (37 percent) if they were able to buy only American-made goods.
}

35 percent believed that increased trade helped American workers. In fact, 59 percent believed that trade hurts American workers.

Related to concern about adverse distributional effects of trade is the view that trade is disruptive. Regardless of whether a sufficient number of new jobs are created to compensate for the jobs lost, many Americans are reluctant to support free trade because trade causes painful adjustments for those who lose their jobs even if they find new jobs relatively quickly. The costs incurred by these workers are not necessarily offset by the creation of new and possibly better jobs. 6

Especially noteworthy is that the sentiments of poll respondents likely reflect altruism rather than self-interest. First, only a small minority of Americans perceive the effects of trade on themselves to be negative. Second, Americans tend to view others as more vulnerable to increasing trade than themselves. Thus, it appears that the concern about the disruptive effects of job loss is for others rather than for themselves.

The concern for workers appears to go beyond U.S. borders. Based on a June 2002 survey conducted by the Chicago Council on Foreign Relations, it is clear that the majority of respondents -93 percent to be exact-think that member countries in international trade agreements should be required to maintain minimum standards for working conditions. Both moral concerns for the foreign workers and economic concerns for U.S. workers appear to affect the respondents' views.

Roughly three-quarters of the respondents to an October 1999 survey by the Program on International Policy Attitudes felt that the United States has a moral obligation to attempt to ensure that workers in foreign countries making goods for the United States do not work in harsh or unsafe conditions. Only 23 percent of the respondents felt that the United States should not judge what working conditions should be in another country. A country's national sovereignty was not viewed as a compelling reason to remain silent. Moreover, the possibility that trade expansion might improve working conditions abroad, even if not to the point of matching

\footnotetext{
An October 1999 survey conducted by the Program on International Policy Attitudes asked respondents to choose between the following two statements. First: "Even if the new jobs that come from freer trade pay higher wages, overall it is not worth all the disruption of people losing their jobs." Second: "It is better to have the higher paying jobs, and the people who lost their jobs can eventually find new ones." The first statement was favored by 56 percent of the respondents, while 40 percent favored the latter statement.
} 
conditions in the United States, was either not considered or ignored.

Additional results reveal a perception that countries that do not maintain minimum standards for working conditions have an unfair advantage that allows for the exploitation of workers and the production of goods at unduly low cost. Here there is concern about the jobs of American workers competing with cheap imports. A related aspect of this argument is that the respondents were not convinced by arguments that forcing higher standards for working conditions in foreign countries might cause elimination of jobs of extremely poor people abroad who desperately need jobs.

Strong support exists for including standards dealing with workplace health and safety, limitations on child labor, the right to strike, the right to bargain collectively, and minimum wages in trade agreements. In addition, contrary to World Trade Organization principles, Americans support unilateral decisions to bar the import of products made under substandard working conditions.

Besides the effects of increased trade on workers, many Americans are concerned that trade adversely affects the environment and that environmental standards should be incorporated into trade agreements. In a June 2002 poll by the Chicago Council on Foreign Relations, 94 percent of the respondents felt that member countries in international trade agreements should be required to maintain minimum standards for protecting the environment. ${ }^{7}$ Support also exists for restricting the importation of goods whose production damages the environment. 8

\footnotetext{
7 Additional evidence supporting environmental standards in the context of trade can be found in the results of a November 2000 poll by Tarrance Group and Greenberg Quinlan Research. Respondents were asked to choose which of the following two statements were closer to their views. First: "Future trade agreements should contain safeguards that require the United States and other countries to enforce strong environmental protections, even if it limits trade." Second: "Expanding trade is critical to the U.S. economy and trade agreements are good for our economy, even if they do not contain strong environmental protections." The majority of respondents, 62 percent, chose the first statement as more closely reflecting their views, while only 22 percent supported not linking trade and the environment in trade agreements.

8 An October 1999 Program on International Policy Attitudes survey asked respondents which of the following statements they agreed with the most. First: "Countries should be able to restrict the import of products if they are produced in a way that damages the environment, because protecting the environment is at least as important as trade." Second: "If countries can put up trade barriers against a product any time they can come up with something they do not like about how it is produced, pretty soon they will be putting up barriers right and left This will hurt the global economy and cost jobs." Overwhelming support was found for the first statement, with 74 percent of the respondents preferring the first statement, while 22 percent supported the
} second statement.
On all these issues of protecting the environment, health and safety, wages and hours, working conditions, and so forth, I suspect that poll results reflect general concerns more than trade concerns per se. In the absence of a specific setting that makes the costs clear, respondents are not likely to favor accepting weaker protections for the environment, for example. Few Americans favor a world trading system in which U.S. policies on environmental and other conditions could be controlled by foreign governments through their willingness to accept goods exported by the United States. Nevertheless, these frequently expressed sentiments indicating a desire to apply U.S. standards to foreign producers do affect U.S. positions in trade disputes.

\section{WHY THE GAP? THE SIMULTANEITY PRINCIPLE}

Two principles, I believe, explain the gap between the economist's view and the public's view on trade. These are what I will call the "simultaneity principle" and the "political-favors principle." I'll discuss the first of these now and the second shortly.

The not very insightful or artful term "simultaneity principle" encompasses the economist's case for free trade. I'm using the term because economists think about the economy through a model in which outcomes in markets are determined together as a consequence of the interactions among markets. Such interactions are represented abstractly in a mathematical model with many equations that must be solved simultaneously.

"Simultaneity principle" sounds complicated, and is meant to. I used to teach the introductory macro course to economics majors and remember well my struggle to explain the characteristics of the basic Keynesian macro model with 10 equations that had to be solved simultaneously. Teaching this material required many hours of classroom time. I could use the model to explain why, for example, an effort by households to increase their saving might have as the primary effect for a time a reduction in total employment, with the precise outcome depending on the nature of monetary policy and the degree of price flexibility. Many other exercises explain counterintuitive outcomes-counterintuitive, that is, until you have worked with the model long enough to change your intuition. It is simply a fact that the outcomes can be complicated to explain when everything in the economy depends on everything else. Indeed, in large models with scores of 
equations it can be difficult even for economists to identify remote and indirect effects. Elaborate simulation investigations are typically required when the models are large and complex.

The economist's case for free trade rests primarily on the fact that imposing or removing trade restrictions invariably helps some firms and people and hurts others but with a positive net benefit for the country as a whole from moving toward freer trade. As I emphasized in a speech in November 2003, a key reason why the general public is reluctant to embrace free trade is that many do not understand the benefits. ${ }^{9}$ And the reason people do not understand the benefits is that they do not understand the interactions and connections across markets. For one example, people may see the genuine costs imposed on workers who lose their jobs to imports, but fail to see the benefits to consumers of lower-priced goods from abroad.

Economists are trained from their first course in the subject to understand the interactions across markets. The interactions are numerous and sometimes remote from the initial disturbance that sets off a chain of such interactions. It is usually possible to explain the nature of these effects to noneconomists, and formal statistical studies can often yield estimates of the magnitude of effects.

Sometimes, an interaction is pretty obvious and it may not be difficult to convey the point. For example, restricting imports of a raw material will have positive effects on domestic producers of the raw material, and their employees, but will hurt domestic users of the raw material. Indeed, by forcing up the price of the raw material, domestic producers of the finished product may find themselves at a competitive disadvantage to foreign companies with a cheaper source of the raw material. Thus, saving jobs in the industry producing the raw material comes at the cost of reduced jobs in industries using the raw material and higher costs to consumers of the finished product.

Most journalists want to smoke out all sides of a story. In the case of a story involving a trade dispute, smoking out the indirect effects is critical to explaining all sides of the story. Understanding the simultaneity principle leads immediately to questions about possible indirect and remote effects of trade restrictions. Those questions need to be

9 The speech was presented to the Louisville Society of Financial Analysts in Louisville, Kentucky, on November 19,2003. It was published in the Federal Reserve Bank of St. Louis Review, March/April 2004, 86(2), pp. 1-7. addressed to economists and industry experts who can uncover the connections across markets and the indirect effects of trade restrictions.

It is important to recognize that the case for free international trade is really part of a more general case for free markets. The analysis of interregional trade within a country is in most respects exactly the same as the analysis of international trade. International trade is a separate subject within economics primarily because it deals with restrictions on trade that do not ordinarily exist between regions of a country.

Economic restrictions are of two sorts - restrictions on trade in goods and services and restrictions on movement of factors of production. In today's world, the most severe of these restrictions is on the movement of labor. Migration across national borders is controlled almost everywhere, and capital mobility is in many cases subject to some degree of restriction.

Although trade is generally free across state borders within the United States, some restrictions do exist. In making the case for free international trade, it is sometimes helpful to refer to analogies created by restrictions within the United States. One example is state professional licensing requirements that prevent doctors, lawyers, and barbers from practicing in states where they are not licensed. Another is regulation of taxis, which may prevent taxis licensed in one jurisdiction from picking up passengers at airports in other jurisdictions. This restriction creates the inefficiency of a taxicab going one way empty, even when potential passengers are waiting in a long line for a taxi. Such examples can be multiplied many times over, and are often useful in explaining the nature of inefficiencies created by trade restrictions.

One of the most difficult interactions to explain is the connection between imports and exports. Even though a country can attract capital for a timeperhaps for a period measured in decades - in the long run, imports must be paid for by exports. Most people understand this point, but not the same point put the other way - exports require imports. Restrictions on certain imports lead, quickly or eventually, either to increases in other imports or decreases in exports. This point is extremely important, for it means that "saving jobs" by restricting imports saves only jobs in the particular protected industry. Saving such jobs necessarily means losing jobs in other import-competing industries or in export industries.

Consequently, one of the points economists emphasize over and over is that saving jobs in partic- 
ular industries does not save employment for the economy as a whole. Economists are sometimes charged with insensitivity over job losses, when in fact most of us are extremely sensitive to such losses. What good economics tells us is that saving jobs in one industry does not save jobs in the economy as a whole. We urge people to be as sensitive to the jobs indirectly lost as a consequence of trade restriction as to those lost as a consequence of changing trade patterns. Indirect job loss is part of the story of trade restriction and can be smoked out if journalists will consult knowledgeable experts.

I've already emphasized that the case for free trade is really part of the case for free, competitive markets more generally. This fact opens up another avenue for informative coverage of trade issues. Why should we be more concerned about job losses from international trade than we are about job losses from domestic competition or changing technology? Outsourcing has been an issue recently. Some firms have replaced staff handling phone inquiries with staff abroad; other firms have replaced call-center staff with automated message systems. Is it better for the caller to be able to talk with a person, who may be abroad, or to go through endless menus of the form, "press 1 if you are a retail customer, press 2 if you are a wholesale customer, press 3 if ..."? When I go through these menus, I'm usually looking for "press 4 to transfer to our competitor."

\section{WHY THE GAP? THE POLITICAL-FAVORS PRINCIPLE}

Trade restriction requires legislative intervention, or regulatory intervention authorized by legislation. That means that trade restriction is inherently political. I do not mean to use "political" in a pejorative sense, for politics is an essential part of democracy and democracy is an essential part of liberty.

Legislation involving economic issues typically creates gains for some and losses for others. Every legislator is aware of this fact. Legislation is typically drawn in such a way to minimize the visibility of the losses, to avoid creating resistance to the legislation and lost votes. Legislation is often drawn to increase the visibility of the gains to those who benefit, to attract votes. However, sometimes legislation hides the benefits, to reduce the possibility that publicity will lead to opposition. Those who benefit, of course, may be well aware of the benefit. It is perfectly natural that legislators should write legislation this way. You and I would do the same thing if we were legislators.
Because they understand the importance of the political-favors principle, journalists know immediately what sorts of questions to ask. When evaluating a particular trade restriction, who gains and who loses? What is the net for the economy as a whole of the gains and losses?

When I read a story that reports only the benefits of trade restriction, I know the story is incomplete. I also know that losers from restriction often do not realize they've been hurt. I'm reminded of the story some years ago of a bank employee who found a way to skim fractional interest payments into his own account. The depositor didn't realize that his account had been rounded off to $\$ 308.27$ whereas his account really had $\$ 308.274$. The extra 4 tenths of a cent, if left in the account, would have earned interest and have led to a larger account balance in the future. The accountant who skimmed a few tenths of a cent from thousands of accounts put a lot into his own account, until he got caught. Many trade restrictions work this way - they cost consumers just a little, but add up to a lot for the protected industry.

Perhaps there is no reason to feel much outrage about such trade restriction, but in most cases legislators would not be able to impose a small sales tax on the good and funnel the revenues to the favored industry. The stratagem works when it is hidden. Telling the full story of any particular trade restriction may require adding up lots of pennies extracted from those who do not realize they are paying.

\section{CLOSING THE GAP}

Once the reasons for the gap between economists and noneconomists are understood, approaches to closing the gap become clear. I've already emphasized the important role of journalists. In this area, as with all other public policy areas in a democracy, a free and enterprising press is essential to effective government in the interest of the nation at large.

As a former university professor, it is natural for me to believe that formal education plays an important role. Nevertheless, every educator is aware of the short half-life of much of the material taught. Students' knowledge usually peaks at exam time, and then starts to decay. What I hope my students retained is some very basic principles, such as the gains from voluntary exchange, and respect for economics as a discipline. Years after formal study, people need to be reminded of the analysis and how it applies to real-life policy issues. Educators 
can play a continuing role, by writing and speaking for noneconomist audiences.

But I began this speech by expressing disappointment over the effectiveness of economists' speeches, and that is why I'm emphasizing the importance of the role of the press today. I've suggested that every story on trade issues, to be complete, must explore who gains, who loses, and the net of gains and losses for the nation as a whole.

Whenever faced with a policy choice that creates winners and losers, we face the difficult problem of somehow weighting one person's benefit against another's loss. The issue appears constantly, and we take two general approaches. The first is that the government does not take property without compensation. The second is that the government stands aside from the competitive market system and lets the chips fall as they may.

Government provides compensation when it takes land for a highway. It is important to note, however, that the compensation is an estimate of fair market value. We understand the loss to a family when government takes land that has been in the family for generations, but we do not try to compensate for the sentimental value of the land. It is simply not possible to maintain a vigorous, growing economy while giving great weight and actual compensation for loss of sentimental value.

Government provides generalized compensation, or adjustment assistance, through unemployment insurance. The United States does not have a general program to compensate owners of capital. Unemployment assistance is relatively limited, as it must be to retain incentives to return to work. Existing legislation also provides some extra benefits for adjustment to losses arising from international trade. My view of this legislation is that in the abstract there is no particular reason to provide more assistance for job loss due to international trade than for any other reason, but as a practical matter such assistance is warranted if it helps to gain acceptance for trade liberalization. We should recognize that many of the arguments for maintaining certain industries in the United States are essentially sentimental, the case being essentially the same as that for avoiding taking land that has been the family farm for generations.

We live in a society that on the whole accepts an economic system that lets the chips fall where they may. Some decry the nature of this system, but its general support rests on the progress and the higher standard of living it affords. We should not underestimate the individual protections built into this system. Our sophisticated market system includes insurance markets that permit individuals and firms to protect themselves against many forms of risk. More importantly, the vitality of our markets creates opportunities for new firms and new employment to absorb those displaced by changing competitive conditions. Our dynamic economic system, and not restrictive trade legislation, provides the best protection for our citizens.

\section{THE BOTTOM LINE}

We all know that a vigorous and just democracy depends on a free and enterprising press. I urge you to keep my two principles - the simultaneity principle and the political-favors principle-in mind when reporting on trade issues. The first requires that you identify the complicated and indirect effects of trade restrictions, and the second requires that you understand the winners and losers from restrictions. I believe that the general voting public will be more likely to favor free trade policies if it understands the issues at a deeper level.

So remember: Every trade story requires at least three sections. One reports who gains, one reports who loses, and one reports the net of the gains and losses for the country as a whole. There is an enormous opportunity here: Sound and impartial reporting case by case by case will do more, I believe, to promote free trade policies than all the economists' speeches extolling the benefits of trade laid end to end.

\section{REFERENCES}

Alston, Richard M.; Kearl, J.R. and Vaughan, Michael B. "Is There a Consensus among Economists in the 1990's?" American Economic Review, May 1992, 82(2), pp. 203-29.

Coughlin, Cletus C. "The Controversy Over Free Trade: The Gap Between Economists and the General Public." Federal Reserve Bank of St. Louis Review, January/February 2002, 84(1), pp. 1-22.

Mayda, Anna Maria and Rodrik, Dani. "Why Are Some People (and Countries) More Protectionist than Others?" Working Paper No. 8461, National Bureau of Economic Research, September 2001.

Poole, William. "A Perspective on U.S. International Trade." Federal Reserve Bank of St. Louis Review, March/April 2004, 86(2), pp. 1-7. 